\title{
Economic Risks of Cheatgrass Invasion on a Simulated Eastern Oregon Ranch
}

\author{
Anna T. Maher, ${ }^{1}$ John A. Tanaka, ${ }^{2}$ and Neil Rimbey ${ }^{3}$ \\ Authors are ${ }^{1}$ Graduate Student, Environmental Science Program, Oregon State University, Corvallis, OR 97331, USA; ${ }^{2}$ Professor, Renewable Resources, \\ University of Wyoming, Laramie, WY 82071, USA; and ${ }^{3}$ Professor, Agricultural Economics and Rural Sociology, Caldwell R\&E Center, \\ University of Idaho, Caldwell, ID 83605, USA.
}

\begin{abstract}
The potential of invasive plants to alter fuel properties over time has implications for the ranchers of semiarid rangelands throughout the world. A prime example of this phenomenon is the cheatgrass (Bromus tectorum L.) invasion of the native shrub-steppe lands in Great Basin of the western United States. The purpose of this study is to develop a bioeconomic model that optimizes simulated ranch behavior given the beginning stages of cheatgrass invasion on a public forage allotment. The bioeconomic model is applied to a typical eastern Oregon 300 cow-calf ranch. Livestock production decisions are simulated over a 40-yr planning horizon using a multiperiod linear programming model. Results showed changes in profit-maximizing ranch management strategies in the form of decreased optimal stocking rates and forage substitution. The net present value of the simulated ranch's income stream declined, and the probability that the ranch cannot meet its full costs of livestock production and would exit the industry increased as a result. These economic impacts were more pronounced with decreased sale price. Sensitivity analysis showed that overall results in terms of ranch behavior were specific neither to the assumed discount rate nor to the assumed percentage of cheatgrass cover (as long as this percentage is within the reference state) on the public grazing allotment. This study introduces a method for managers to quantify impacts on ranches from fuel-altering invasive plants on public lands, emphasizing the importance of including information about native and invasive forage production characteristics and wildfire frequency as a function of the state of invasion.
\end{abstract}

Key Words: beef cattle, BLM, Bromus tectorum, invasive, rangeland economics, wildfire

\section{INTRODUCTION}

The potential of invasive plants to alter fuel properties over time has implications for the ranchers of semiarid rangelands throughout the world. These plants can generate an invasive plant-fire regime cycle that aids the invader in gaining dominance (Brooks et al. 2004). A prime example of this phenomenon is the cheatgrass (Bromus tectorum L.) invasion of the native shrub-steppe lands in the Great Basin of the western United States. Many ranchers in the western United States depend on their public grazing permit to stay in the ranching business (Rowe and Bartlett 2001; Torell et al. 2002). As a result, the success of cheatgrass control on public lands has economic implications for the rancher that holds a public grazing allotment.

When cheatgrass initially invades a site, the spring production peak of cheatgrass allows the grazing season to begin earlier as long as ample production from native perennial forage species remains for the rest of the grazing season (Platt 1959). However, as cheatgrass continues to increase, significant changes in existing fire regimes and reductions in native perennial species can occur (Chambers et al. 2007). Although this region has historically experienced fire return intervals in the range of $30-100 \mathrm{yr}$, areas that become dominated by cheatgrass can see fire return as often as every 5 yr (Knapp

Correspondence: John A. Tanaka, University of Wyoming, Dept 3354, 1000 E University Ave, Laramie, WY 82071, USA. Email: jtanaka@uwyo.edu

At the time of research, Tanaka was Associate Professor, Agricultural and Resource Economics, EOARC-Union Station, Union, OR 97883, USA.

Manuscript received 28 July 2010; manuscript accepted 5 January 2013

(c) 2013 The Society for Range Management
1996; Brooks and Pyke 2001). As cheatgrass invades new areas of the Great Basin rangelands (Brooks and Pyke 2001), its invasive plant-fire regime cycle presents a new source of risk to public forage availability.

Few studies have examined the impacts of invasive plant species on the profitability of the ranch. Satyal (2006) assessed the ranch-level cost-effectiveness of various cheatgrass treatment methods (herbicide, grazing, controlled burns, and integrated). The model included the forage production tradeoff between cheatgrass (assumed to decrease) and native grasses (assumed to increase) as the result of treatment over time. Changes in risk of wildfires (i.e., return interval) as the result of treatment were not considered.

Other studies have modeled the impacts of public land restoration policies (Torell et al. 2002) and woody invasive species treatment strategies (Aldrich et al. 2005; Teague et al. 2008) on the profitability of the ranch. These studies included risks typically considered by the rancher. Typical risks considered are variations in market prices and precipitation (Torell et al. 2010). However, the reaction of ranchers to wildfire risks that would constrain public land forage availability is unknown.

A new model is needed in order to better understand the ranch-level, economic risks of cheatgrass control and treatment on public lands The purpose of this study is to develop a model that optimizes simulated ranch behavior given the beginning stages of cheatgrass invasion. The model incorporates the trade-offs among cheatgrass forage production, declines in native species forage production, and reduced public forage availability as the result of cheatgrass-related wildfires. The probability that the public allotment is not available as forage is included in the model as an additional seasonal forage 
availability constraint. The with-fire (WF) model is compared to results from a without-fire (WOF) model to gain an understanding of the ranch response in terms of changes in 1) forage utilization, 2) stocking rates, and 3) profitability and probability of not being able to meet full costs of livestock production.

\section{THE MODEL}

This study uses herbaceous biomass data that was gathered during the pretreatment (control) year of the Sagebrush Steppe Treatment Evaluation Project (SageSTEP; SageSTEP 2007). These data provided the forage production characteristics of an ecologically healthy Bureau of Land Management (BLM) allotment in the Great Basin region exhibiting the initial stage of cheatgrass invasion. These data were gathered on four 80-ha plots in Lake County, Oregon, on the Hart Mountain Gray Butte and Rock Creek study sites. The study site description follows and can be found on the SageSTEP website (SageSTEP 2007). The elevation at the Gray Butte and Rock Creek sites is $1497 \mathrm{~m}$ and $1509 \mathrm{~m}$, respectively. The sites' common vegetation consists of primarily Wyoming big sagebrush (Artemisia tridentata Nutt. subsp. wyomingensis Beetle \& Young [Asteraceae]), bluebunch wheatgrass (Pseudoroegneria spicata [Pursh] A. Löve [Poaceae]), squirreltail (Elymus elymoides [Raf.] Swezey; syn. Sitanion hystrix [Nutt.] J.G. Smith), Sandberg bluegrass (Poa secunda J. Presl), Indian rice grass (Achnatherum hymenoides [Roemer \& J.A. Schultes.] Barkworth), Thurber's needlegrass (Achnatherum thurberianum [Piper] Barkworth [Poaceae]), and cheatgrass.

The bioeconomic model builds from a ranch-level economic model that has been used elsewhere with various modifications (Torell et al. 2002; Stillings et al. 2003; Aldrich et al. 2005; Satyal 2006; Tanaka et al. 2007; Torell et al. 2010). This model simulates long-term cattle production with a profit-maximizing objective in a dynamic setting and specifies cash and forage availability constraints. Research has shown that most western ranchers are willing to accept minimal rates of return on their investment in the ranch and grazing permits and include noneconomic factors in their investment decisions (Torell et al. 2001). Ranchers are considered utility maximizers rather than strictly profit maximizers (Torell et al. 2001; Bartlett et al. 2002). To be consistent with the theory of utility-maximizing behavior, the model incorporates the rancher's budget constraint (off-ranch income, borrowing capacity, and wealth rather than strictly revenue from cattle production) and considers individual preferences of consumption (including nonmarket values).

The model returns the probability that the simulated ranch will exit the industry given changes in the economic environment. Economic theory distinguishes between short-run and long-run production decisions available to a profit-maximizing firm in a perfectly competitive market. In the short-run, capital is fixed, and the firm should continue to produce (not shut down) even if it is operating at a loss (negative profits) as long as it covers average variable costs (variable costs per unit production). The idea is that in the short run, fixed costs must be paid regardless of whether or not the firm chooses to produce. In the long run, however, total revenue (price $\times$ quan- tity) must at least cover full costs of production (fixed and variable); otherwise, the firm should choose to exit the industry.

Unlike the strictly profit-maximizing agent, the western rancher's opportunity cost of industry exit includes forgoing nonsubstitutable quality-of-life attributes, and ranchers will likely continue in the ranching business until they are forced to leave (Torell et al. 2001). To account for this behavior, the simulated ranch can meet full costs of production (fixed and variable) from a variety of income sources (ranch, off-ranch, wealth, and borrowing capacity). However, if the ranch cannot meet full costs of production from these income sources, the ranch is projected to exit the ranching business. This is similar to the idea of utility maximization in utility theory. To maximize utility, the economic agent should spend all of his or her budget constraint (which includes borrowing or savings) but should never exceed this constraint (Nicholson 2005).

The model is quantified by a General Algebraic Modeling System (Brooke et al. 1998) multiperiod linear programming model. Torell et al. (2002, fig. 1) provides details as to how the model transfers animals, forage, and cash between years and seasons. In our model, ranch-level impacts are explicitly considered as the result of an initial stage of cheatgrass invasion on the rancher's public forage allotment.

\section{Objective Function}

The rancher's objective is to choose ranch management practices that maximize ranch profit $(\pi)$ over a 40 -yr planning horizon. The simulated ranch chooses the quantity of livestock to produce in each time period over multiple time periods, subject to costs of livestock production, which includes available forage resources. Income in future years is discounted at rate $(r), r=7 \%$ (income in the future is worth less than income today). The objective function takes the following form:

$$
M a x \pi=\sum_{t=1}^{T} N P V_{t}=\sum_{t=1}^{40}\left(T R_{t}-T V C_{t}\right) *(1+r)^{-t}+\text { TValue }_{T}
$$

where

$$
\begin{aligned}
T R_{t} & =\text { liveclass } * \text { salewt } * \text { saleprice }+ \text { crops } * \text { cropsale } \\
T V C_{t} & =\text { forage } * f c s t+\text { cattle } * \text { cattlecst }+ \text { crop*cropcst }
\end{aligned}
$$

Equation [1] states that the net present value $(N P V)$ of the livestock operation is equal to total revenue $(T R)$ minus total variable costs $(T V C)$ in each time $(t)$ period. TR is determined by the number of cattle in each weight class (liveclass) multiplied by the associated weight for that class (salewt) times the sale price (saleprice).

In addition to selling portions of the herd, income from crops is also included in the model. Crops are calculated as the quantity of crops sold times the market price of each crop (cropsale) in each time period. Inputs to cattle production include various types of available forage (forage), including crop aftermath, which are multiplied by their associated forage cost $(f c s t)$, the main focus of this study. Other variable costs include cattle (cattlecst) and crop (cropcst) to make up TVC. 
Borrowing costs and fixed costs are also part of the model though not represented in the equation above. These costs are discussed below in the section "Cash Flow Equations." The terminal value (TValue) is necessary to account for all future returns from the herd following the end of the 40-yr planning period (otherwise, the ranch would sell all of its livestock in period $T)$.

The realization of the objective function varies from year to year based on the herd size. The model chooses the optimal (profit maximizing in this case) herd size based on the resources available. Herd expansion from year to year is restricted to the herd size in the previous year and the biological constraints of reproduction (purchases of replacements are not an option in the model). Replacement heifers can be retained or sold either as calves or as yearlings (prior year calf crop retained). The model is therefore dynamic and optimizes over time by considering the trade-off between the value of future production and forgone sales this year.

The simulated ranch adjusts management strategies if model parameters change (as compared to a baseline model of no change) according to the profit-maximizing objective and cash flow constraints. Management strategies available in the model include seasonal forage substitution (intra-annual) and adjustments in stocking rates (interannual). Seasonal forage substitution can compensate for changes in forage availability. That is, the herd could be moved to other lands that are available in that season. For example, in the event that public land is unavailable, deeded rangeland animal unit months (AUMs) can be substituted, but this affects the number of AUMs available on deeded range in all other seasons in that year. Therefore, interseasonal dynamics, as a function of the total AUMs available for each forage type, constrain the extent to which this substitution can take place. The cost of AUMs for each forage type also plays a role in the substitution decision. For example, if deeded AUMs (relatively low cost) need to be saved to substitute for the loss of public forage (lowest cost) later in the year, this means that a higher-cost type (e.g., hay) must be fed in those seasons with reduced deeded range AUMs. The mix of strategies chosen by the model, that is, decisions about quantity and timing of forage substitutes and herd-size reductions, are those that maximize long-run profit.

\section{Cattle Transfer Equations}

Cattle transfer equations are used to simulate changes in the herd size and makeup over time (ranch operation equations of motion). Equations related to operation characteristics and specific assumptions regarding cull and replacement requirements are provided in Aldrich et al. (2005).

\section{Forage Sources}

Assumptions regarding available forage sources, (i.e., public forage substitutes and their prices) must be carefully considered when applying this model. Available forage sources are area specific. The typical method employed is to use enterprise budget operation descriptions and data from the area to define a "representative ranch." These specifics are important for accurately representing the degree to which a ranch is dependent on its public forage allotment. For example, in some areas of the Great Basin, severe weather conditions limit the availability of grazing opportunities during winter months. Aldrich et al. (2005), for example, assumed that the simulated ranch purchased hay for feed during a minimum of 4 winter months. However, purchased hay is generally not considered a viable management option for most months in the Great Basin region because of limited availability and high cost. Feeding purchased hay is therefore not a viable substitute when public forage is utilized only during the spring and summer months.

Similarly, private land leasing is also included as a forage option in many applications of this model (Aldrich et al. 2005; Torell et al. 2010). Including private leased forage as an option in the model involves careful assumptions regarding prices. Private lease prices are area specific and generally a function of the scarcity of private lease lands in the area. Aldrich et al. (2005) used an exponential cost function to reflect scarcity of nearby private pastures for lease. Torell et al. (2010) assumed two constant prices, low and high, for private lease land to reflect the cost of transporting livestock to nearby private lease options vs. lease options at a considerable distance. As a representative ranch is modeled, it is assumed that all ranches in the area would be affected similarly by cheatgrass invasion. For this reason, private lease forage is not included as an option in our model due to an assumed lack of supply.

\section{Forage Supply and Demand Equations}

The model specifies available forage sources and forage transfer equations by season. The model is initially calibrated such that there is enough available forage (supply) in each season to meet the needs (demand) of the equilibrium herd size. The simulated ranch must produce or purchase enough forage to feed the herd throughout the year. The optimal herd size in a given year is a function of both the herd size in the previous year and the quantity of forage available in its most restricted season in the current year.

\section{Cash Flow Equations}

Cash flow, borrowing capacity, and sources of off-ranch income (i.e., alternative income sources) constrain the profit-maximizing objective function. Livestock sales, off-ranch income, and crops are potential sources of cash for the ranch. It is assumed that short-term borrowing can occur to cover expenses. Any funds borrowed must be paid the following year. Repeat borrowing can occur, though all loan obligations must be paid in full by the end of the 40 -yr planning horizon. Furthermore, net returns from the ranch, off-ranch income, and accumulated wealth must be greater than or equal to production expenses, fixed expenses, and loan obligations during each year. If this requirement is not met, it is assumed that the ranch is forced to exit the ranching business, as full costs of production cannot be met through all of the sources of income. The term "forced" is used specifically because it is assumed that the simulated ranch exits the ranching business only when all modeled income and borrowing options are exhausted.

\section{Wildfire Constraint}

The bioeconomic model in this study introduces a wildfire constraint on public forage availability. Postfire conditions on public lands preclude domestic livestock grazing for at least two growing seasons (Knapp 1998). It is necessary to 
understand the key fuel-altering characteristics of the invasive plants in question and how this will affect access to the public forage allotment. For example, cheatgrass decreases the time between fires as it continues to invade. However, other fuelaltering invasive plants may increase the time between fires but cause more catastrophic fires that may require many years of recovery time following a fire. This model incorporates the risk of wildfire into the model according to the fire-return interval associated with the observed level of invasion and a Monte Carlo simulation approach. The parameters of the wildfire constraint in this bioeconomic model can easily be changed to reflect the allotments recovery time and the fire-return interval associated with other fuel-altering invasive plants.

\section{Model Specification}

As an example of the proposed bioeconomic model, this study specifies the model for a typical eastern Oregon cow-calf operation with a grazing allotment in the Great Basin region. The equilibrium herd size for the simulated ranch is 300 mature cows. The "representative ranch" production processes and other operating assumptions are based on the Oregon State University Enterprise Budget EM8470 (Kerns et al. 1997). Costs and prices from this document were adjusted to 2005 dollars using standard Consumer Price Index techniques. A detailed description of the representative ranch in terms of key model parameters is presented in Maher (2007).

The model is calibrated to ensure that the available forage sources meet or exceed the yearlong needs of the 300-head ranch (the equilibrium herd size). Assumed forage demand according to animal class can be found in Aldrich et al. (2005). It is assumed that a minimum herd replacement requirement exists for cows and heifers and that replacements come from heifer calves and yearlings saved each year rather than from purchased brood cows. The cow-calf operation is assumed to operate in a perfectly competitive industry. Perfect competition requires perfect knowledge about prices and production (Nicholson 2005).

While other applications of this model use stochastic beef prices, this study uses constant prices in order to isolate the economic risks as the result of the wildfire constraint on public forage availability. One hundred sets of 2005 random livestock sale prices were averaged according to livestock class to create a set of "average sale" prices. Adding and subtracting one standard deviation from the mean prices resulted in a "high" and a "low" price set.

The available land (forage) options for this representative ranch are the BLM allotment, deeded range, alfalfa hay, and crop aftermath. The seasons of use for each land type considered are constrained in the model, as shown in Table 1. Forage demand from the herd in each of seven seasons is constrained to be less than or equal to the amount of forage available in that season. Practices such as feeding hay during the summer are not considered viable management options.

The quantity of forage available on the BLM land by forage type and season is explicitly considered in this model. The BLM land type is considered to be available only in the seasons outlined in Table 1 . However, the ecological characteristics of the forage available from the BLM land type are further specified in accordance with an initial stage of cheatgrass invasion. That is, the quantity of AUMs of forage varies by season and forage type (native and cheatgrass forage) according to specific growth functions (for another example of this method, see Satyal 2006). Table 2 shows the relative forage growth of native grasses and cheatgrass available in each season.

Both the Hart Mountain Gray Butte and the Rock Creek study sites are considered to be in the reference state as defined by Pellant et al. (2005). While the observed level of cheatgrass invasion varies across each site, for the purposes of this study, the herbaceous biomass data used are those associated with the highest level of invasion on each site, approximately $15 \%$ cheatgrass cover (i.e., approaching a threshold level of invasion). Fifty percent of the herbaceous biomass on these study sites is assumed to be available as forage in the model. The herbaceous biomass data from the SageSTEP project included both native and nonnative grasses and forbs. Percent cover information was the only available measurement that was separated specifically into cheatgrass and native grasses. The relative percent cover of native grass to cheatgrass was therefore calculated and multiplied by the herbaceous biomass to determine the proportion of biomass attributed to cheatgrass and native grasses. The number of $\mathrm{g} \cdot \mathrm{m}^{-2}$ for the two sites was averaged. The amount of forage production attributed to native grass and cheatgrass on the ranch's BLM allotment is 33.59 $\mathrm{g} \cdot \mathrm{m}^{-2}\left(0.91\right.$ AUMs $\left.\cdot \mathrm{ha}^{-1}\right)$ and $25.12 \mathrm{~g} \cdot \mathrm{m}^{-2} \quad(0.69$ AUMs $\left.\cdot h a^{-1}\right)$, respectively.

The risk to the ranch from wildfire is randomly imposed on the model using a Monte Carlo approach. This land type has a $15 \%$ cheatgrass cover and is associated with a $20-40-y r$ fire interval (D. A. Pyke, personal communication, June 2007). Assuming this frequency of wildfire, 100 sets of fire years are randomly generated. Grazing on the BLM land is allowed during the year of the fire. The BLM allotment is not an available forage source for the $2 \mathrm{yr}$ immediately following the randomly generated year of the fire. For each single model iteration, the randomly generated year(s) that the BLM allotment will be excluded from the ranch's forage sources is known with certainty. The Monte Carlo approach is used to account for the fact that wildfire(s) could have occurred at any point during the 40-yr planning horizon and to reduce potential bias about assuming that the fire occurred in any particular year. Consistent with this approach, the model is run 100 times, one for each randomly generated fire set. Results are averaged over the 100 random fire sets.

\section{Scenario Definition}

Two scenarios are considered here. The first scenario includes the wildfire constraint and is referred to as the WF model. The second scenario does not consider the possibility of wildfire (no restrictions on the public land grazing permit in any years) and is referred to as the WOF model. Ranch impacts as the result of the interaction between changes in beef prices and stochastic wildfire years are considered by examining three sale price scenarios: high, average, and low.

\section{RESULTS}

Results of the WF model are presented as averages over the 100 randomly generated wildfire years. Comparison of the WF and 
Table 1. Seasonal forage supply for the simulated cow-calf enterprise is restricted according to the season of use for each land type.

\begin{tabular}{lll}
\hline Season & Date season starts & \multicolumn{1}{c}{ Land type } \\
\hline 1 & 15 March & Deeded range \\
2 & 1 April & Deeded range, BLM allotment \\
3 & 15 June & Deeded range, BLM allotment \\
4 & 15 July & Deeded range, BLM allotment \\
5 & 1 September & Deeded range, BLM allotment \\
6 & 1 October & Deeded range, Raised meadow hay \\
7 & 15 November & Raised meadow hay \\
\hline
\end{tabular}

WOF models showed changes in profit-maximizing ranch management strategies as the result of the specified cheatgrass wildfire constraint. The ranch became increasingly less profitable with lower cattle sales prices. In both the WF and the WOF models, all iterations showed that the ranch could not cover its costs of production and were forced to exit the ranching industry when subjected to the low sale price scenario. Observations of changes in ranch management profit-maximizing strategies are therefore limited to the high and average sale price scenario.

\section{Forage Use by Season}

The WF model showed a small overall decrease in average yearly BLM and deeded range forage use. This is the result of reduced average yearly herd sizes and seasonal shifts in intensity of use caused by the response of the ranch to wildfires. Seasonal declines of BLM forage use coincided with an increase in deeded range use in the same season. The simulated ranch's average yearly use of its BLM allotment declined by the greatest amount in season 2 . Forage utilization on BLM land declined nearly $19 \%$ and $18 \%$, given the high and average sale price scenarios, respectively. The ranch adjusted to this decrease, in part, under high sale prices with a $36 \%$ increase in BLM forage utilization in season 5. In the average sale price scenario, the change in use in season 5 is negligible.

\section{Herd Size}

The 300 mature cow herd size consistently maintained in the WOF model was no longer feasible in the WF model. The timing of the herd adjustments in the WF model depended on the price level and BLM forage availability as defined for the different model iterations. As an example, consider results for two randomly selected iterations, as shown in Figures $1 \mathrm{~A}$ and 1B. The wildfire constraint impacts optimal herd size over the planning horizon in two key ways: 1) there is a gradual decline in herd size in the years prior to the wildfire, and 2) there is a dramatic reduction in herd size to 184 brood cows (a 38\% reduction) in the two postwildfire years.

In iterations in which the simulated ranch is able to recover from the economic impacts of the wildfire, the rate at which the herd size is rebuilt depends on the year in which the fire occurred and the price level (Fig. 1A). Results showed that the ranch is more vulnerable to the wildfire impacts in the early years of the planning horizon. The ranch also rebuilds the herd
Table 2. The native grass and cheatgrass rate of growth on the BLM allotment land type assumed for each season for the simulated cow-calf enterprise (National Resource Conservation Service, US Department of Agriculture 1996).

\begin{tabular}{lcc}
\hline & Growth functions & \\
\hline Season & Native grasses & Cheatgrass \\
\hline 2 & 0.00 & 0.40 \\
3 & 0.25 & 0.80 \\
4 & 0.60 & 1.00 \\
5 & 1.00 & 0.50 \\
\hline
\end{tabular}

size at a slower rate under the average sale price scenario than it does under the high sale price scenario.

If the ranch is able to recover from a second fire over the 40yr planning horizon, the herd size is reduced once again to the minimum of 184 brood cows, as shown in Figure 1B. The same factors that influence the recovery rate from the first fire also influence the recovery rate after the second fire. These same factors, coupled with the number of years between fires, influence whether the ranch is able to recover from the second fire or fails to meet full costs of production and exits the industry.

\section{NPV of Profit and Industry Exit}

The WF model is unable to maintain the 300 cow-calf herd size afforded in the WOF. As a result, both the NPV of ranch profit and the ability of the firm to meet full costs of production decrease. For the high sale price scenario, the NPV returned from the WF model (\$828260) is nearly 6\% less than that of the WOF model $(\$ 879030)$. The NPV returned from the WF model $(\$ 513250)$ is $3.5 \%$ less than that of WOF model $(\$ 523230)$ for the average price scenario. These are averages over the iterations of the model in which the simulated ranch was able to meet full costs of production.

Table 3 shows the probability the firm will not be able to cover its full costs of production using all sources of income and will instead exit the ranching industry. Results are shown as averaged for all randomly generated 100 wildfire years (100 model iterations) according to sale price scenario. Results are further divided according to the number of fires occurring in the 40-yr planning horizon. Most notably, the probability that the firm will exit the industry increases by $22 \%$ given the average sale price as compared to the high sale price scenario. Under the average price scenario, the occurrence of a second fire forces the ranch to exit the industry.

\section{Sensitivity Analysis}

Sensitivity analysis is used in economic models to determine whether important parameter changes affect the outcomes. In this study, the sensitivity of the model to changes in the assumed economic discount rate and biological level of cheatgrass invasion were tested for such an effect. The NPV of the firm's income stream in both models was evaluated using a discount rate with $r$ equal to $4 \%$ and $10 \%$. Results of the sensitivity analysis showed that regardless of the assumed discount rate, there was still downward pressure on the NPV in the WF model as compared to WOF model. The probability 

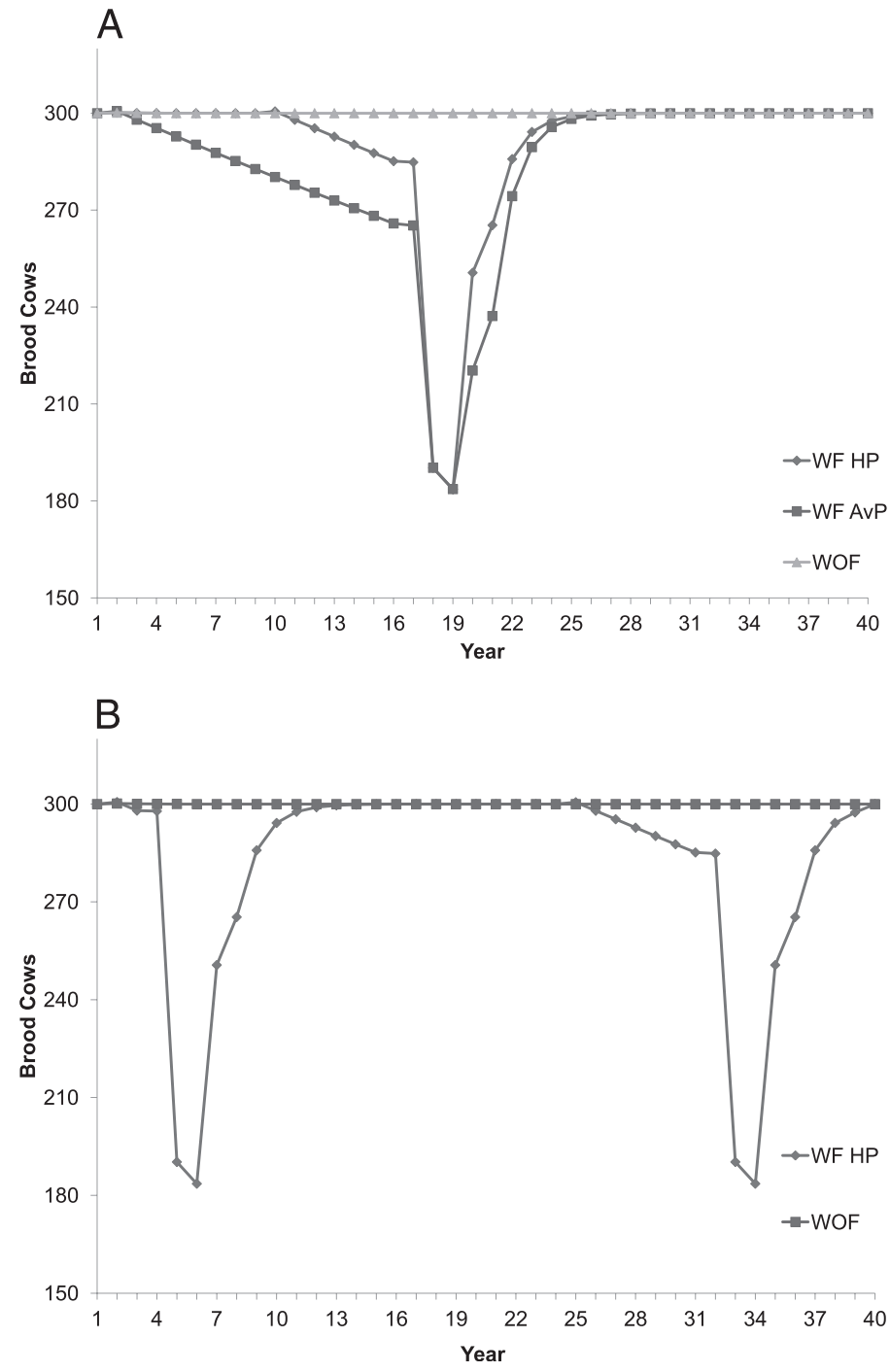

Figure 1. Optimal herd size adjustments in the with-fire model for high sale prices (WF HP) and average sale prices (WF AvP) for selected iterations of the simulated cow-calf enterprise as compared to the without-fire (WOF) model. A, Shows this comparison for a single fire year occurring in year 17. B, Shows this comparison for two fire years occurring in years 4 and 32 .

that the ranch would not be able to pay for the full production costs was unaffected by the assumed discount rate.

The second sensitivity analysis was performed to determine if the results of this study depended on the level of cheatgrass invasion assumed (referred to in this section as the "most invaded" level). The analysis considered forage available by grass type from two lower levels of invasion. The herbaceous biomass data from the study site provided two additional levels of invasion, categorized here as "more invaded" and "least invaded." The available $\mathrm{g} \cdot \mathrm{m}^{-2}$ for each of the three levels is shown in Table 4.

For the lower levels of invasion, the WF model still showed a lower NPV of the enterprise as compared to that of the WOF model. Under the high sale price scenario, NPV declined by $7 \%$ for the two lower levels of invasion as compared to $6 \%$ for the assumed level of invasion in the model. With the average sale price scenario, lower levels of invasion showed greater economic impacts. The NPV declined by $12 \%$ for the least
Table 3. The probability that the simulated cow-calf enterprise will stay or exit the industry is based on its ability to meet the full costs of production in the with-fire (WF) model and are shown according to sale price scenario and fire frequency.

\begin{tabular}{lcccc}
\hline & $\begin{array}{c}\text { No. of model } \\
\text { iterations }\end{array}$ & $\begin{array}{c}\text { No. stay in } \\
\text { business }\end{array}$ & No. of exits & $\begin{array}{c}\text { Probability of } \\
\text { bankruptcy }\end{array}$ \\
\hline High price & $\mathbf{1 0 0}$ & $\mathbf{8 9}$ & $\mathbf{1 1}$ & $\mathbf{1 1 \%}$ \\
Single fire & 76 & 71 & 5 & $7 \%$ \\
Two fires & 24 & 18 & 6 & $25 \%$ \\
Average price & $\mathbf{1 0 0}$ & $\mathbf{6 8}$ & $\mathbf{3 2}$ & $\mathbf{3 2 \%}$ \\
Single fire & 76 & 68 & 8 & $11 \%$ \\
Two fires & 24 & 0 & 24 & $100 \%$ \\
\hline
\end{tabular}

invaded and by $9 \%$ for the more invaded level. This is considerably greater than the $4 \%$ decline in NPV at the assumed (most invaded) level of invasion. The result of a $4 \%$ decline in NPV under the low price scenario should therefore be considered a lower bound estimate of the negative impact on $N P V$ resulting from the imposed wildfire constraint.

\section{DISCUSSION}

Return intervals of wildfires in the Great Basin are affected by the amount of cheatgrass in the stand. Understanding the impact of fire return intervals on ranches is an important component to understanding the economic risks from cheatgrass invasions. There are certainly other social and economic impacts from wildfires on other ecosystem goods and services. If fire return intervals are shortened and public land policy requires a period of nongrazing use following the fire, then the impact on ranches and communities affected by them will be important to understand as cheatgrass management strategies are developed. If current policies cause ranches to no longer be able to cover the full costs of livestock production from all income (on- and off-ranch) sources, these ranches will eventually leave the industry with concomitant impacts on local and regional communities.

The results of this study reflect the importance of the rancher's access to their public forage allotment. Both sale price scenarios show the same sharp decline in optimal stocking rates during the $2 \mathrm{yr}$ following the wildfire. As a low-cost forage option, the seasonal dependency of western ranchers on public forage has long been established (Taylor et al. 1982; Greer 1995; Torell et al. 2002). Studies have found that lack of access to federal forage for even a short time, in the absence of an economically viable alternative, can force the rancher to reduce the number of livestock on a ranch (Taylor et al. 1982; Torell et al. 2002). When it is economically viable, substituting available forage for lost public grazing land has been found to result in lower economic impacts than the strategy of reducing herd size (Bartlett et al. 2001; Torell et al. 2002). Similarly, the results of this study show that substituting available deeded range (relatively low cost) AUMs for lost public forage AUMs is profit maximizing. Herd size reductions likely became costeffective because average yearly herd size is restricted within a single year by the season of use with the least amount of viable (cost effective) forage and total deeded range AUMs were not 
Table 4. The quantity of available BLM allotment forage used in the sensitivity analysis was based on data from the Hart Mountain, Oregon, SageSTEP study site and is shown in $\mathrm{g} \cdot \mathrm{m}^{-2}$ according to the assumed level of cheatgrass invasion (all within in the reference state of invasion).

\begin{tabular}{lccc}
\hline Grass type & Least invaded & More invaded & Most invaded \\
\hline Native grass & 63.94 & 54.80 & 33.59 \\
Cheatgrass & 20.81 & 29.16 & 25.12 \\
\hline
\end{tabular}

enough to compensate for this reduction in public forage AUMs.

If other forage substitutes were available that were not considered in this application, such as privately leased land, these additions would be expected to lessen the economic impact of reduced access to the rancher's public allotment. However, the cost of substitutes is a critical factor. Negative ranch-level impacts will still be reflected to some extent as long as the public land allotment remains the lowest-cost forage option. In addition, if development pressures are present and predicted to increase, the number of forage substitutes, particularly private leased land and hay resources, are not likely to increase (Rowe and Bartlett 2001).

Torell et al. (2010) explicitly considered alternative enterprise and stocking management strategies that could minimize the impact of unfavorable forage production years during periods of drought. Although this study included a private lease forage option, results of the cow-calf enterprise scenario still showed that selling a large portion of the herd was optimal in dry, low forage production years. However, a cow-calf and yearling enterprise scenario was evaluated and was found to provide more year-to-year flexibility in the stocking rate. This enterprise option increased net returns over that of the cow-calf operation. This alternative enterprise scenario could be explored in future applications of the WF model. This could reduce the need for reductions in cow numbers in years of exclusion from public forage allotments.

The results of this study indicate that the economic risks of cheatgrass invasion depend on the economic climate (sale price scenario) faced by the rancher. The profit-maximizing strategy exhibited in this study is for the simulated ranch to slowly lower the stocking rate in the years prior to the years(s) of the wildfire. Producing a smaller herd size means a drop in returns in subsequent years of the model, so the optimal solution is to smooth out this cost over the planning horizon. Under the average price scenario, greater declines in stocking rate were required in the years prior to the fire and were kept lower for a longer period of time than under the high price scenario. Similarly, it is optimal to rebuild the herd at a slower rate under the low price scenario than under the high price scenario.

Furthermore, comparison of the impacts of the wildfire constraint on NPV shows that the simulated ranch has more to lose at the high price scenario than given the low price scenario (decrease in the net present value of the firms income stream of approximately $\$ 50000$ vs. $\$ 20000)$. On the other hand, Table 3 shows that under the high sale price scenario, the representative ranch is more likely to meet full costs of production given historically high sales prices as compared to the average sales prices. Most notably, the ranch is unable to meet full costs of production if a second fire occurs within the 40-yr planning horizon under the average sale price scenario. The indication is that with historically average cattle prices, ranches in the Great Basin may become less economically viable due to an increase in the frequency of wildfires from the invasion of cheatgrass.

Although wildfire years are randomly generated according to an assumed wildfire-return interval, our model does assume perfect information in terms of the year of the fire for a given iteration of the model. It is unlikely that the rancher can obtain perfect information about the probability and timing of the wildfire as it is modeled here. The gradual decline in animal numbers prior to the fire is due to the deterministic nature of the model. Producers cannot employ such a risk management strategy (reduction in herd size prior to the actual fire) if there is no information about the probability (risk) and timing (uncertainty) of reduced access to their allotment. With no prior knowledge of wildfire, the operator would have to reduce its stocking rate only after the fire has already occurred, resulting in a lower NPV in a real-world scenario than that presented here. Therefore, it is likely that the results of this study underestimate the economic risks associated with cheatgrass invasion.

The assumption of perfect information regarding forage production and access to forage sources is common in these ranch models. Torell et al. (2010), for example, assumed perfect climate forecasts, and therefore drought years were known with certainty. Such certainty in weather forecasts is no more obtainable than perfect wildfire forecasts. However, understanding optimal behavior under perfect information gives insight into the profit-maximizing ranch management strategies and therefore the value of obtaining additional information about changes in fire frequency and public land policies regarding wildfire recovery time. Therefore, while the assumption of perfect information gives insight into optimal ranch management strategies to reduce economic risks from cheatgrass invasion, further research is needed to understand how profitability is impacted if this assumption is relaxed.

To the extent that cheatgrass treatment reduces economic risks from invasion, results from this study suggest that ranchers may be willing to pay for successful cheatgrass treatment on public lands. It is important to note that the economic risks explored here are for ranchers subject to the initial stages of cheatgrass invasion. Whether this result holds with increased levels of cheatgrass invasion is an avenue for further research. Satyal (2006) found that in heavily invaded cheatgrass areas (greater than $80 \%$ cover), the simulated ranch incurred greater costs from treatment of cheatgrass on their public allotment than from no treatment. These results could be explained by the high costs of treatment at high levels of invasion. Other studies have argued that past a certain point, it is financially difficult or impossible to return to a previous, lesser state of invasion (Stringham et al. 2003; Pellant 2005). The results of our study indicate that a complete account of the economic risks from cheatgrass management strategies requires the modeling of changes in the probability of wildfires (e.g., reductions in wildfire frequency) as the result of treatment. Therefore, use of a wildfire constraint in the Satyal (2006) study may have yielded different results.

If the goal is to quantify ranch impacts, stochastic sale prices and precipitation would more accurately reflect the market and 
climate forces considered by the ranching enterprise. Constant prices and precipitation were necessary in this application of the model in order to make direct inferences from the imposed wildfire impact regarding changes in simulated ranch behavior. Past studies that have employed this ranch optimization model without the wildfire constraint have shown year-to-year changes in the optimal stocking rate as the result of stochastic sale prices and precipitation. If this stochasticity were added to the WF model, the optimal management strategies would account for year-to-year variability in prices and precipitation in addition to variability in access to the public allotment.

Similarly, application of this bioeconomic model to other fuel-altering invasive plant species requires changes in specific assumptions and parameters to fit the study area in question. For example, it is possible that the land may need more or less than $2 \mathrm{yr}$ to recover following a fire or that only a portion of the allotment would be unavailable following a fire. These specifics depend on the invasive plant being evaluated, public policy regarding postfire recovery, and the ecological characteristics of the allotment.

\section{IMPLICATIONS}

The combined risks from sale price level and the wildfire constraint leave the simulated ranch more vulnerable (i.e., less able to meet full costs of production) than if simply subject to changes in price level alone. However, the results of this study show that informed ranchers can reduce the economic risks associated with fuel-altering invasive species if they are able to plan in advance. Thus, given more information about changes in wildfire frequency and ample notice about reduced access to their public allotment, ranchers can minimize economic costs through forage substitution and changes in stocking rates. This implies that advanced knowledge of invasive species treatments, such as prescribed burns on public allotments, would also be preferred by the rancher over that of an unforeseen wildfire event.

\section{LITERATURE CITED}

Aldrich, G. A., J. A. Tanaka, R. M. Adams, and J. C. Buckhouse. 2005. Economics of western juniper control in central Oregon. Rangeland Ecology \& Management 58:542-552.

Bartlett, T. E., L. A. Torell, N. R. Rimbey, L. W. Van Tassell, and D. W. McCollum. 2002. Valuing grazing use on public land. Journal of Range Management $55: 426-438$.

Brooke, A., D. Kendrick, And A. Meeraus. 1998. GAMS—a user's guide. Available at: http:// www.gams.com/docs/gams/GAMSUsersGuide.pdf. Accessed 4 December 2007.

Brooks, M. L., C. M. D’Antonio, D. M. Richardson, J. B. Grace, J. E. Kelley, J. M. Ditomaso, R. J. Hobbs, M. Pellant, and D. A. Pyke. 2004. Effects of invasive alien plants on fire regimes. Bioscience 54:677-688.

Brooks, M. L., AND D. A. Pyke. 2001. Invasive plants and fire in the deserts of North America. In: K. E. M. Galley and T. P. Wilson [EDs.]. Proceedings of the Invasive Species Workshop: the role of fire in the control and spread of invasive species, fire conference 2000: the 1st National Congress on Fire Ecology, Prevention, and Management; 27 November-1 December 2000; San Diego, CA, USA. Tallahassee, FL, USA: Tall Timbers Research Station. Miscellaneous Publication No. 11. p. 1-14.

Chambers, J. C., B. A. Roundy, R. R. Blank, S. E. Meyer, and A. Whittaker. 2007. What makes Great Basin Sagebrush ecosystems invasible by Bromus tectorum? Ecological Monographs 77:117-145.
GreER, A. J. 1995. Federal grazing permits and federal dependencies in southeastern Oregon. Rangelands 17:4-6.

Kerns, L., B. Turner, F. Obermillere, J. Tanaka, B. Eleveld, D. Chamberlain, G. Delaney, R. Hathaway, D. Knutson, and W. RigGs. 1997. Enterprise budget: 350 cow/calf operation, High Desert Area. EM8470. Corvallis, OR, USA: Oregon State University Extension Service. $4 \mathrm{p}$.

Knapp, P. A. 1996. Cheatgrass (Bromus tectorum L) dominance in the Great Basin Desert: History, persistence, and influences to human activities. Global Environmental Change 6:37-52.

KnapP, P. A. 1998. Spatio-temporal patterns of large grassland fires in the Intermountain West, U.S.A. Global Ecology and Biogeography Letters 7:259272.

Maher, A. T. 2007. The economic impacts of sagebrush steppe wildfires on an eastern Oregon ranch [thesis]. Corvallis, OR, USA: Oregon State University. $159 \mathrm{p}$.

National Resource Conservation Service, US Department of Agriculture. 1996. Electronic Field Office technical guide. Available at: http://www.nrcs.usda.gov/Technical/ efotg. Accessed 10 June 2007.

Nicholson, W. 2005. Microeconomic theory: basic principles and extensions. 9th ed. Mason, OH, USA: South-Western. 671 p.

Pellant, M., P. Shaver, D. A. Pyke, and J. E. Herrick. 2005. Interpreting indicators of rangeland health, version 4. Technical Reference 1734-6. Denver, CO: U.S. Department of the Interior, Bureau of Land Management, National Science and Technology Center, BLM/WO/ST-00/001+1734/REV05. 122 p.

PLATt, K. B. 1958. Plant control: some possibilities and limitations I: the challenge to management. Journal of Range Management 12:64-68.

Rowe, H. I., AND E. T. BartLetT. 2001. Development and federal grazing policy impacts on two Colorado counties: a comparative study. In: L. A. Torell, E. T. Bartlett, and R. Larrañaga [EDS.]. Proceedings of a Symposium Sponsored by the Western Coordinating Committee 55(WCC-55): annual meeting of the Society for Range Management; 17-23 February 2001; Kailua-Kona, HI, USA. Las Cruces, NM, USA: New Mexico State University's Agricultural Experiment Station. p. 59-74.

SAGESTEP. 2007. SageSTEP Project Fact Sheet. Available at: http://www.sagestep. org. Accessed 13 September 2007.

SatYaL, V. H. 2006. Economic and social impacts of restoration: a case study of the Great Basin Region [dissertation]. Corvallis, OR, USA: Oregon State University. $127 \mathrm{p}$.

Stillings, A. M., J. A. Tanaka, N. R. Rimbey, T. Delcurto, P. A. Momont, and M. L. Porath. 2003. Economic implications of off-stream water developments to improve riparian grazing. Journal of Range Management 56:418-424.

Stringham, T. K., W. C. Krueger, and P. L. Shaver. 2003. State and transition modeling: an ecological process approach. Journal of Range Management 56:106-113.

TAyLoR, R. G., E. T. BARTLett, AND K. D. LAiR. 1982. Seasonal dependence on federal forage in Colorado. Journal of Range Management 35:634-636.

Tanaka, J. A., N. R. Rimbey, L. A. Torell, D. T. Taylor, D. Balley, T. DelCurto, K. Walburger, and B. Welling. 2007. Grazing distribution: the quest for the silver bullet. Rangelands 29(4):38-46.

Teague, W. R., W. E. Grant, U. P. Kreuter, H. Diaz-Solis, S. Dube, M. M. Kothmann, W. E. PINCHAK, AND R. J. ANSLEY. 2008. An ecological economic simulation model for assessing fire and grazing management effects on mesquite rangelands in Texas. Ecological Economics 64:611-624.

Torell, L. A., S. Murugan, and 0. A. Ramirez. 2010. Economics of flexible versus conservative stocking strategies to manage climate variability risk. Rangeland Ecology \& Management 63:415-425.

Torell, L. A., N. R. Rimbey, J. A. Tanaka, and S. A. Balley. 2001. The lack of a profit motive for ranching: implications for policy analysis. In: L. A. Torell, E. T. Bartlett, and R. Larrañaga [EDS.]. Proceedings of a Symposium Sponsored by the Western Coordinating Committee 55(WCC-55): annual meeting of the Society for Range Management; 17-23 February 2001; Kailua-Kona, HI, USA. Las Cruces, NM, USA: New Mexico State University's Agricultural Experiment Station. p. 47-58.

Torell, L. A., J. A. Tanaka, N. R. Rimbey, T. Darden, L. Van Tassell, and A. Harp. 2002. Ranch-level impacts of changing grazing policies on BLM Land to protect the Greater Sage-Grouse: evidence from Idaho, Nevada and Oregon. Caldwell, ID, USA: Policy Analysis Center for Western Public Lands. PACWPL Policy Paper SG-01-02. 20 p. 